\title{
Theistic Humanism and the Hermeneutic Appraisal of the Doctrine of Salvation
}

\author{
Chiedozie Okoro \\ Department of Philosophy, Faculty of Arts, University of Lagos Akoka, Yaba, Nigeria \\ Email: chiedozieokoro@gmail.com
}

Received September $22^{\text {nd }}, 2012$; revised October $20^{\text {th }}, 2012$; accepted November $7^{\text {th }}, 2012$

\begin{abstract}
This essay uses theistic humanism as a super structure to do a hermeneutic appraisal of the doctrine of salvation in a pluralistic world. It operates on the assumption that reality is multidimensional, just as human belief systems and cultural perspectives are diverse. More importantly, is the point that most countries on the African continent house a potpourri of belief systems, prominent among which are Christianity, Islam and Traditional African Religion (ATR). Thus, theistic humanism offers us the opportunity to do a pluralistic assessment of salvation, thereby making myriad interpretations of the notion of salvation possible. Again, the essay neither intends to examine the meaning of God nor is it interested in analyzing how God gets manifested in human existence. Rather, the basic objective is to consider the various ways in which salvation has been conceived in relation to the human condition. In the process of our delineation, it shall be shown that salvation as a doctrine can be conceived from two principal angles which are: 1 ) the perspective of religion and 2) the non-religious or secularist perspective. Whereas the first presents other-worldly account of salvation, the second presents a this-worldly account of salvation. The import here is that since in the most ordinary sense, God is all about perfection and human goodness, it implies that the quest for salvation in whatever dimension, deliberately or inadvertently, amounts to the search for the ultimate essence or the most perfect state of reality which religions call God. Consequently, the burden of this essay is to show that salvation is an ideal state of reality which humankind is striving to attain. Bearing in mind that humans as free beings that have the capacity to interpret salvation either anthropocentrically or theocentrically, thereby, making the myriad presentations of salvation possible; one is of the view that metaphysical notions of reality are also contagious of salvation. Hence, for monists and reductionists the way to salvation is narrow and single, while for the pluralists the way to salvation may be narrow but diverse. Thus, since the hermeneutic appraisal of salvation is hinged on the assumption that belief systems are diverse and multi-faceted, the essay privileges the pluralistic presentation of salvation over and above the monistic presentation of salvation.
\end{abstract}

Keywords: Theistic Humanism; Hermeneutics and Salvation

\section{Introduction}

Hermeneutic delineation of any issue is meant to yield interpretations which are intended to reveal or bring to light facts which hitherto appear hidden. The hermeneutic procedure is sometimes referred as the dialectics of concentric circles because, the hermeneutic method is usually cyclical in projection, propped up by the principle of duality, which in turn, mutates on a trilogy. The trilogy in the hermeneutic procedure comprises analysis, revelation and synthesis. This makes the hermeneutic discourse to proceed in circles or simply cyclical. The cyclic nature of hermeneutic discourse shows that things in the universe are interconnected, that is to say, the conflict in the universe notwithstanding. In essence, the hermeneutic method does not see the conflict of opposites as antagonistic. Hermeneutic appraisal of events or arguments sees the conflict of opposites as natural and therefore, complementary. The complementarity of opposites in this instance, defines what we have designated as the concept of duality in hermeneutic discourse.

Due to the peculiar nature of the hermeneutic procedure, Martin Heidegger makes strict distinction between "logos as logic" and "logos as discourse". The former depicts logos as ratio, logical deliberation or ratiocination, while the latter por- trays logos as understanding, intelligibility, that which reveals or brings a thing into light. This act of revealing things in a new light is designated by Heidegger as the "hermeneutic situation" (1962: p. 275). Accordingly, he explains that: "The function of "logos as discourse" is to make clear that which is talked about" (p. 59). The distinction made between "logos as logic" and "logos as discourse" marks the difference between traditional logic and hermeneutics. Whereas the former delights in critical discussion of issues, the latter moves from critical discussion of issues to interpreting issues in a new light in such a way that vistas of images are opened up, which should crystallize into new concepts.

Expectedly, the hermeneutic appraisal of salvation is bound to proceed cyclically and in this concentric cyclical delineation, new interpretations shall be created which would seem to deflate existing platitudes. Nevertheless, the intent is not to foist meanings upon existing theories, but to review them in a new light. Besides, the subjection of the doctrine of salvation to the hermeneutic crucible, privileges the juxtaposition of views, thereby, making the procedure of our discourse rigorous and the language terse. The rigour of discourse and the terseness of language here posited, derive from the fact that our act of theorizing intersperses three principle areas namely philosophy, 
religion and politics. The objective is to examine how philosophical discourse can assist in fashioning out a way of mitigating religious conflict, which in turn generates political unrest, thereby, making our discourse to be speculative, comprehensive and technical.

Furthermore, the hermeneutic appraisal of salvation is meant to be existential, it is neither existentialist nor is it about existentialism. The word existential is an adjective which describes or qualifies the noun existence or human existence in general. The word existentialist can either be a noun or an adjective. As a noun it refers to a philosopher who belongs in the school of existentialism, in which case its plural form will be existentialists. As an adjective it refers not to the philosopher but to the school existentialism itself. The term existentialism, on the other hand, is "a philosophical movement which begun in the 19th century centered on individual existence that denies that the universe has any intrinsic meaning or purpose, it requires people to take responsibility for their own actions and shape their own destinies" (Microsoft Encarta Premium, 2009). This means that whereas the word existential refers to the totality of human existence or human existence in general, existentialism would refer to a thought process for speculating about human existence, while existentialist describes the person who speculates about human existence as well as this act of speculating about human existence.

From the hermeneutic point of view therefore, we regard salvation as the soul or mind of humankind striving to attain an ideal state of reality. It is a transition and a transformation to perfection. In religious terms, perfection would mean a state of total freedom, emancipation and finality, beyond which there is no further change. But from the secular point of view, perfection is ongoing activity to which there is no end. In phenomenological terms, we speak of the theory of self-reflexivity as that way of cultivating the attitude of watch over self, otherwise described as the attitude of eternal vigilance. Again, in religion, humans as finite, sentient and imperfect, yet free beings, strive ceaselessly towards the attainment of perfection by way of letting their souls harmonize with an ideal state of infinite, perfect and absolute reality called God. Religion assumes that man is finite and imperfect, this accounts for the reason why man strives to attain a state that is infinite and perfect. Religious notion of salvation as such is the struggle of the finite to become infinite, the imperfect to become perfect and the transformation of the mortal into the immortal, the immanent into the transcendent etc. Religiously, man conjectures that there are "this world" and "the other world", "the world of here" and "the world of there". In this sense, salvation becomes the struggle by man to attain the status of the God reality. Hence, the bases for religious notion of salvation include factors such as evil, sin, judgment and after life. Because there is afterlife, there is death (i.e. a transition from mortal to immortal). Besides, concepts such as hope and faith (in the unknown) make sense because there is eternal life. Perhaps it is in this sense that Norris Clarke states as follows:

In some real and genuine way God is affected positively by what we do, that he receives love from us and experiences joy precisely because of our responses; in a word, that his consciousness is contingently and qualitatively different because of what we do ... it is that God is constantly working in and through us with his supportive and collaborative power, supporting both being and action of every creature. But he allows this power to be determinately channeled by the respective natures, especially the free-will decisions of creatures. God lets us be according to our own free initiatives (1977: pp. 92,96).

In religion, God as infinite spirit supposedly stands detached from, yet directs the affairs of mortals who are expected to call upon their free-will and use their initiatives to bring into reality God's plan. This sounds paradoxical if not contradictory. To overcome this anomaly in religious notion of salvation, secularism makes the quest for salvation an entirely human affair. Hence, in the Kantian sense, we say, the quest for salvation is a self-imposed obligation.

Secularism treats salvation as the struggle by humans towards self-realization, self-actualization and self-emancipation, which should result into the improvement of the human condition. This may be the reason why contrary to Sartre, Heidegger appraises death in a positive light. From the Heideggerian perspective, death is regarded as a natural process of ensuring balance or order on earth. The fact is that without death the earth will become impossible and uncomfortable to live in. Death inspires our hopes, it makes us to be resolute and focused, it rekindles our ambitions to strive and fortifies our plans to achieve and to conquer. This view of Heidegger seems to confirm the secularist position that salvation is entirely a thisworldly affair. Perhaps, it is along this line of thought that Sartre completely rejects the idea of a cosmic policeman who oversees human affairs. Sartre and most existentialists see the cosmos and the things therein as utensils for the use of humans. Faith then becomes ambition, while hope is propelled by aspirations.

Nevertheless, religion and secularism hold issues as void or nothingness, culture and morality, and judgment and punishment as germane to the doctrine of salvation, though with some degree of differences. The void or nothingness we talk about here simply refers to a primeval state or point from which formation begun, which is regarded to be boundless and limitless. For instance, in the Egyptian and Christian cosmogonies, the cosmology of Thales of Miletus and Darwin's evolution theory, water remains a primary stuff from which all things evolved. And whereas Thales identified water as the elementary substance from which every other thing derives, the Egyptian cosmogony states that life began from "primordial abyss, Nun" (Onyewuenyi, 1994: p. 179) also variously addressed as primeval waters Nun, chaos, the formless, the boundless and the hidden, while Tefnut (air) hovered over the face of the void. Again, the Christian cosmogony states that in the beginning "the earth was without form, and void, and darkness was upon the face of the deep, and the spirit of God moved upon the face of the waters" (Genesis 1: p. 2). Following Darwin's evolution theory, "extensive geological investigation shows that in the early geosynclinals period, the water that permeated the earth's surface continually transported dissolved substances from their places of formation to their places of accumulation and concentration” (Ogundowole, 2002: p. 6). Beyond the biological stage of evolution, the physical perspective states thus: "In the beginning it was dark and cold. There was no sun, no light, no earth, and no solar system. There was nothing, just the empty void of space" (Williams, 1999: p. 1). The foregoing simply shows that both secularism and religion accept void, emptiness or nothingness, as primordial, implying that the quest for salvation is in actual fact, the search for the ultimate beginnings, and in that 
line of thought, also signifies the quest for the ultimate end.

Besides, whereas both secularism and religion agree that tolerance and discipline are required for peaceful-co-existence, social harmony, social stability, societal progress and good neighbourliness; religion, on its part goes a step further to state that the aforementioned merely helps to prepare us for salvation in the hereafter. For this reason, religion advocates that living a pious or holy life is a basic criterion for overcoming sin, meaning that once anyone is capable of leading a sinless life; such individual is qualified to enter into heaven. Secularism, on its part, may not bother so much about after life, its basic concern therefore, would center on living a fulfilled life guided by reason here on earth.

Furthermore, whereas secularism and religion regard punishment and judgment as measures for controlling human conduct for the purpose of societal cohesion; religion, however, further assumes that there is judgment in the hereafter (i.e. the last day) and eternal punishment for sinners. In line with this eschatological discourse, Christianity speaks of the Second Coming of Christ, while Islam speaks of the coming of the Mahdi.

The eschatological discourse is taken to a different dimension by Marxism. According to Chinweizu (2005), Marxism presents a secularist perspective to the issues of God, prophet, priesthood and heaven. "For though it is officially atheistic or Even anti-theistic, Marxism has history as its God, Marx as its Prophet, Leninists as its Priesthood, the Kremlin as its Holy of Holies, Red square as its Mecca and Communism as its Heaven" (the italicized are mine; p. 145).

Marxism opines that the contradictions characteristic of human history will be overcome with the emergence of the communist state. But it appears that there is controversy about what Marx really meant by the communist state. E. K. Ogundowole (1988) explains that the Moscow institute of Marxism-Leninism and Martin Milligan hold that by communism Marx meant “crude equalitarian communism" (p. 88). Dirk J. Struck and Donald Hodges, on their part, hold a contrary view. In the view of these two "since Marx speaks of communism as the necessary state of the next future, as the negation of negation, communism for Marx may well mean human emancipation beyond the abolition of private property, after alienation has been conquered” (p. 89). The latter assertion of Dirk Struck and Donald Hodges about communism, made available by Ogundowole, seems to capture more appropriately Marx's view. As Marx (1969) states in the 1844 Paris Manuscript: "Communism is the necessary pattern and the Dynamic principle of the immediate future, but communism as such is not the goal of Human development-the structure of human society" (p. 106).

It can only then be inferred that for Marxism, communism in a way, represents an ideal state of affairs called heaven. This teleological view of Marx which states that the dialectics of matter and history will culminate at the evolution of communism has come under serious criticisms. Some like Chinweizu describe Marxism as a secularist religion. And by this statement, Chinweizu means that Marxism is merely an atheistic and secularist representation of Judaism and Christianity. Just as Judaism and Christianity speak of the end of the world, so too does Marxism.

It would seem then that Marxism presents a more consistent secularist account of the doctrine of salvation. However, it is interesting to note that existentialists, particularly Sartre and Heidegger, disagree with this Marxian description of human existence. For existentialists, human existence precedes human essence. Besides, existence is ongoing activity which cannot be achieved outside human history. From the existentialist perspective therefore, salvation is not just a self imposed obligation, rather, as Sartre posits, the non-existence of God puts on humans the heavy burden of an endless quest for freedom. The quest for freedom is endless because every new stage of existence that humans attain presents higher levels of challenges.

\section{Theistic Humanism and Religious Interpretations of Salvation}

This segment of this essay is premised on the principle of polymonotheism (2010: p. 190) propounded by Maduabuchi Dukor, which forms a cardinal part of the theory of theistic humanism. Central to the principle of polymonotheism are the concepts of pantheism and panpsychism, both of which buttress the point that God manifests to different peoples differently, thereby making a case for the myriad interpretations of salvation, even within religion.

Consequently, in this segment, we make evaluation of the doctrine of salvation within some world religions from two principal perspectives namely 1) monistic or monotheistic religions to which belong Judaism, Christianity and Islam 2) nonmonistic or non-monotheistic religions to which belong Confucianism, Buddhism, Jainism, Hinduism and Traditional African Religion (ATR). The term non-monistic or non-monotheistic is used instead of the term polytheism because; it is sometimes argued that Confucianism, Buddhism, Jainism and Hinduism are not religions in the strict sense, let alone being polytheistic. Besides, it can also be argued that Traditional African Religion is not polytheistic, but pluralistic and humanistic. This point has been aptly made in another paper titled "Theistic Humanism and the Critique of Monotheism as the most evolved Religion”. For now, our focus is on the object of the segment of this paper which is intended to examine the religious perspectives to salvation. Another point to note is that monistic/monotheistic religions create a dichotomy between here (i.e. earth) and the hereafter (i.e. heaven), in which case, for these religions the universe progresses upon a linear dialectical scale. Non-monistic/non-monotheistic religions, on the other hand, do not create a polarity between this-world and the other-world, in which case, they assume that the universe progresses cyclically. However, in both monistic/monotheistic and non-monistic/nonmonotheistic religions, belief systems or thought processes are built around some personalities who are regarded as saviours, prophets, sages or divinities. We now proceed to the treatment of the object of this segment, which is about the religious evaluation of salvation.

Finitude makes humans seek for eternity. But finite humans have infinite essences, often described as either metaphysical or spiritual. To realize their infinite essences in concrete terms, humans project their metaphysical essence into the supervoid. Perhaps, it is based on the foregoing that J. I. Unah states as thus: "There is a divine essence in man which he tries to actualize in his daily commerce with the world and the universally recognized institution for the actualization of such divine essence is religion” (1995: p. 74). Based on the foregoing, Ludwig Feuerbach asserts that God is nothing but the alienation of our metaphysical qualities. In the same vein, Sigmund Freud argues that humans conjecture of a fatherly figure in whom they trust and depend. Perhaps, it is in this sense that religion speaks 
of a heavenly father who oversees human activities. The latter point is succinctly captured by John B. Noss (1990) in the following words:

All religions say in one way or another that man does not, and cannot, stand alone. He is vitally related with and even dependent on powers in Nature and Society external to himself. Dimly or clearly, he knows that he is not an independent center of force capable of standing apart from the world (p. 14).

Almost all religions talk about man's mythological fall from glory. For this reason, piety or righteousness is set as a criterion for re-attaining the lost state of glory. This means that religion as a social institution has an earthly purpose. The aforementioned point is amplified by Nurudeen Alao who states thus:

There is a common grape that is after the heart of every religionist. That grape is often buried under a heap of procedural verbiage. The grape that is common to all religions is not in their rituals; the grape is in their common object of helping man to actualize the divine in him, of assisting man to ascend to the pedestal of goodness. It lies in the objective of making each man his brother's keeper and of eradicating all evils in the society (1988: p. 2).

From a socio-philosophical perspective therefore, religions the world over have a common objective as follows: "1) that of enabling man to rise to the pedestal of goodness and eradicating all evils in society, 2) that of assisting in moulding social behavior and 3) that of ensuring a dialogical and meaningful human relationship" (Unah, 1995: p. 74, the itemizing is done by me). Along this line of thought, T. D. P. Bah lists five points that are characteristics of all religions thus:

1) The conceptions of God the gods.

2) The conceptions of man in relation to the cosmic order (stressing more the spiritual than the corporeal nature of man).

3) Human behavior founded either on human or non-human reality.

4) The aim of a particular religion in relation to man's earthly life.

5) The destiny of man, that is, as it pertains to individual and collective goals for our earthly existence (1997: pp. 157-158).

The fact that religious notion of salvation is basically otherworldly notwithstanding, elevation into the ideal state of glory is not possible without some earthly conditions. Perhaps, this explains why in Christianity, the personality of Jesus Christ is exemplary to the attainment of salvation. Expressing believe in and patterning one's life after Christ, bestows on one righteousness and grants one the grace to heaven. This happens to be the central theme of the Pauline epistles. In his epistle to the Romans Paul says: "No one is righteous-all have sinned and come short of the glory of God. But by the free gift of God's grace all are put right with him through Christ Jesus, who sets them free" (Romans 3: pp. 4,23). The way to be righteous in God through Jesus Christ is to be "born again" (John 3: p. 3). This makes Jesus Christ the symbol of redemption.

But within Christendom a debate ensues between Catholicism, Protestantism and Pentecostalism as to the correct interpretation of salvation. This point is aptly made by Francis Schaeffer in his work Escaped from Reason. In what he calls the struggle between the Upper and Lower chambers, which depicts the struggle between nature and grace, faith and reason,
Schaeffer explains the difference in perspectives between Catholic Humanism and what he calls the "autonomous" of Protestantism. Within Catholic Humanism, Thomas Aquinas represents the point at which Platonism and Aristotelianism converge. In Aquinas, says Schaeffer, though there is a unity between nature and grace, but grace is placed over nature. This means that God is over and above man. In spite of the fall of man, he (man) still has the intelligence (i.e. portraying independence or autonomy) to rationalize about the grace of God, which in Schaeffer's view, portrays Aquinas as one who truly represents "the real birth of humanistic Renaissance" (1968: p. 10). But with John Calvin and Calvinism, emerged the Reformation's view of salvation which is opposed to the Renaissance. Simply:

The Reformation repudiated both the Aristotelian and Neo-Platonic presentation ... It said that the root of the trouble sprang from the old and growing Humanism in the Roman Catholic Church, and the incomplete theory of the fall in Aquinas's theology which set loose an autonomous man. The Reformation accepted the biblical picture of a total fall. The whole man had been made by God, but now the whole man is fallen, including his intellect and will... only God was autonomous (p. 19).

Contrary to the Catholic and Aquinas's notions of humanism, which set us free, the Reformation holds the view that there was no autonomous person. By the expression autonomous freedom is meant "a freedom in which the individual is the centre of the universe, it is freedom without restraint” (p. 34). The line was thus drawn between Catholic "orthodoxy" and the "religious existentialism" or "the modernism" of Protestantism and Pentecostalism. "Aquinas opened the door to an independent man downstairs, a natural theology and philosophy which were both autonomous from the scriptures” (p. 51), but the Reformation denies knowledge of such a theology and philosophy. With this emergent dichotomy says Schaeffer: "Religious truth is separated from the historical truth of the Scriptures. Thus there is no place for reason and there is no point of verification. This constitutes the leap in religious terms (Ibid.).

Whereas for Catholicism, salvation is won through "the Revelation of God in Christ alone-Christ died for our salvation, but man had to merit the merit of Christ” (p. 20). This involves a divided work of salvation in which the humanistic element is very important. The Reformation, on the other hand, tries to overcome the dualism in the Renaissance, a process in which Humanism becomes the modern man's sorrow. For the Reformation, "God made the whole man and the whole man is important-he is interested in the whole man, and the result is unity” (pp. 28,29). The Reformers held a contrary view about man's redemption. For them, salvation is a finished work, man has no part in it other than to accept and believe in the finished work of Christ. Opposed to Catholicism, the emphasis for the Reformers is "Scripture Alone and Faith Alone" (p. 20). In this new scheme of things, comments Schaeffer:

No autonomous or humanistic, religious or moral effort of man can help, one is saved on the basis of the finished work of Christ as he died in space and time in history, and the only way to be saved is to raise the empty hands of faith and, by God's grace, to accept God's free gift-Faith Alone (Ibid.). 
Schaeffer further asserts that the campaign for faith as the criterion for wining salvation attained its climax in the philosophy of Soren Kierkegaard who placed Fith over and above Reason. According to Schaeffer, Kierkegaard was concerned with the fact that reason had overshot its bounds, he therefore, refuted the absolutism and obscurantism that characterized Catholicism and Hegelianism. Again, within the arena of religion, Kierkegaard was concerned with the meddlesomeness of sacrament, church and the clergy in the relationship between believers and their God. Thus for Kierkegaard, organized or centralized religion is a fraud. Thus, "The gist of Kierkegaard's polemics against organized Christianity is that it puts emphasis on numerical strength and that such emphasis on number is a counterfeiting of Christianity and distancing of God" (Unah, 1995: p. 55).

With the advent of Christian modernism (religious existentialism), the era of Christian "born again" religion emerged, which is more pronounced in Pentecostalism than in Protestantism. Christian Pentecostalism is known for the dictum-is it in the bible? The assumption is that all that we need to know are already contained in the Bible, therefore, all that we require is to confess that Jesus Christ is lord and saviour. This was how absolute faith entered into the Christianity. As time wore on, Absolute Faith became Blind Faith. Little wonder existentialists describe Christian religious faith as-a blind leap into a dark hole. In this wise, there is no much difference between Christian notion of salvation and that of Judaism and Islam which see salvation as deriving from total surrender to the will of Yahweh or the will of Allah. One cannot even think of believing or not believing in God, because, humans as part of God's creation, remain significant, insofar as they surrender to the will of God. By implication, our quest for salvation is merely part of God's plan.

Consequently, when Feuerbach in The Essence of Christianity compares Christianity with Judaism, and goes ahead to describe Christianity as the religion of "a free-thinker, of criticism and of freedom which distinguishes inward moral purity from external physical purity” (1989: p. 32), one understands this assertion to be indicative of Christian orthodoxy, not Christian existentialism. Feuerbach describes Judaist notion of salvation thus: "The Israelite trusted himself to do nothing except what was commanded by God; he was without will even in external things; the authority of religion extended even to his food" (Ibid.). Needless to say, this assertion is likewise true of Islam and Christian Pentecostalism. For these two, God controls the totality of our lives, He (God) knows about every minute details of our lives.

The religions of the Far East and Traditional African Religion seem to hold views that differ from those of Christianity, Judaism and Islam. Unlike the Semitic and Hellenistic religions, the African and Asian religions do not believe in the termination of the physical universe. Rather than speak of the final termination of the physical world and the evolution of a purely spiritual world, African and Asian religions hold that the physical universe is in constant evolution, such that it keeps augmenting the spiritual world. Again, for African and Asian religions, prophets and messiahs are not of much importance to the discourse on salvation. Salvation is won individually through self-discipline, not by believe in any prophet or messiah or God for that matter. This is so because God-the great essence is already in every individual person as a little or small essence. All that one needs to do is to live a disciplined and accomplished life to win salvation. Further, unlike the Semitic and Hellenistic religions, African and Asian religions do not speak of an appointed date for final judgment, nor do they distinguish between eternal salvation and eternal damnation or perdition. There is no eternal punishment anywhere either here or in the hereafter. Punishment is here and now. By the law of retributive justice or karma, each soul keeps reincarnating until it attains perfection or salvation. It is in this sense that Hinduism speaks of samsara, Buddhism of anata and Traditional African Religion of the ancestral world.

Within the confine of Traditional African Religion for instance, God is a "Wholly Other" (Eboh, 1993: p. 3) who is both transcendent and immanent. To buttress this point, Eboh makes reference to the Igbo ontological world view thus:

Chi is seen as "a small big-life". Chukwu is the Big-Life, Life Per se, Life Par Excellence. Every other thing that exists has a life in so far as God "portions out" or allows it a share of the big-life ... So, chi is the life principle which is given to everything that exists by the Big-Life Principle Par Excellence, or chi is a Portioned out life" in everything, "a small Big-Life in everything (Ibid. 4).

The above aptly captures the African thought process which regards the world to be organic or alive. This makes African religious world view to be pantheistic, whereby, the visible and the invisible are intertwined. Salvation is thus a process of cyclical progression in which a soul evolves through a centrifugal and centripetal movement (i.e. reincarnation) until it attains perfection. An accomplished soul passes on to the ancestral world as the past, souls awaiting rebirth belong to the spirit world as the future, while living mortals represent the present.

For Hinduism, salvation is a matter of relationship between Brahman and Atman, technically rendered as Brahman-Atman. Brahman-Atman is the "the doctrine in the Upanishads of the connection between the universe and humanity, the ultimate and the individual God and man-Atman is the true inner self of all" (St. Elmo, 1979: p. 21). St. Elmo explains that "Brahman is God, the ultimate, without attributes or any quality representing the image of man, or described by any human words or categories of thought” (pp. 20-21). Atman, on the other hand, represents the ultimate principle translated as self or soul. What St. Elmo means to say here is that atman defines the identity and individuality of things. But this does not mean that atman is more ultimate than Brahman because, "every atman whether in man, beast, fish, insect or plant, is one with the infinite” (p. 7), that is, Brahman. Since atman as the identity and individuality of things derives its source from Brahman, it means that the totality of existence is represented by Brahman-Atman. By logical entailment, it also means that Brahman-Atman alone exists and "if Brahman-Atman alone exists, the universe can be said to be one with unity of purpose” (pp. 7-8). In Hinduism therefore, salvation is attained when atman becomes one with Brahman or attains a state of unity with Brahman. To buttress this point St. Elmo makes reference to Martin Luther King Jr. who in one of his sermons described Hindu notion of salvation thus: "On the Hindu view, truth lies within. Self-realization is the supreme good. One reaches ultimate reality by an inward journey. This inward ascent is marked by discipline and persistence” (p. 8).

Confucianism is mostly regarded as an ethical than spiritual religion. It is rather concerned with realizing ones purpose on earth and about how societal existence can be organized for the 
good of all. Confucius describes human self-actualization in the following words;

If you have become one with the infinite, you have no personal likes and dislikes. If you have become one with the great Evolution (of the Universe), you are one who merely follow its changes (cited by St. Elmo, 1979: p. 81).

Confucianism as such is more concerned with the search for useful knowledge to "self" and to "others". About this matter St Elmo makes Chu Hsi's view about Confucian conception of salvation assessable as follows: "Great Ultimate involves both matter and form ... it is the principle of things to be actualized, than to remain purely a potential. Actualization then requires both principles (i.e. matter and form or the mind of Heaven and Earth) as its actuality” (p. 80). Chu Hsi goes ahead to accuse other Asian religions of having anti-social tendencies. According to him, Buddhism for instance, "held nature to be empty whereas Confucianism held it to be active and full of potentialities" (Ibid.).

The point is that Buddhism portrays more of an idealistic philosophy than a religion. Perhaps, it is for this reason that Buddhism is fondly referred to as an atheistic religion. It does not hold in gods or God, it has no notion of messiah or prophet who acts as intermediary between humans and their creator or through whom humans come to gain salvation. Buddhism is entirely about self-development, it is about self-reliance, and its aim is to train humans on the act of self-mastery. To attain the state of perfection which in Buddhist terms is called nirvana, individual souls must rely on "self" or the "overself". For this reason, Buddhism pays homage to man's overself. This can be seen in the Buddhist chant-Om! Mani Pad-me Hum-meaning "Hail to man's overself” (Rampa, 1956: p. 10). For Buddhism, therefore, our souls keep going through a circle of rebirth until it attains the state of nirvana. The way to attain nirvana is through internal self discipline or "integral yoga" (St. Elmo, 1979: p. 9).

In The Elementary Forms of the Religious Life, Emile Durkheim sheds further light on the Buddhist notion of salvation. He explains that though Buddhists recognize the importance of figures such as Buddha, Indra, Agni and Varuna but not as prophets or messiahs. For Buddhists, these figures are important only as they show the way to self-mastery. Buddhists believe that though Buddha founded Buddhism, but he wasn't one perfect, he became perfect, he wasn't eternal, he became immortal. This means that for Buddhists, salvation is gained through self-development, self-actualization and self-realization. The focus for the Buddhists is not Buddha, but the attainment of the state of nirvana realized through the observance of the tenets of Buddhism. It is in the light of this that Durkheim wrote:

Buddhism consists primarily in the idea of salvation, and salvation supposes only that one know the good doctrine and praise it. To be sure, this could never have been known if Buddha had not come to reveal it; but when this revelation had once been made the work of Buddha was accomplished. From that moment he ceased to be a factor necessary to the religious life. The practice of the four holly truths would be possible, even if the memory of him who revealed them were completely obliterated (1968: p. 47).

In Buddhism, nirvana as a state of perfection is not repre- sented in any image, either of God or of man. It rather represents an ideal state of perfection comparable to Plato's eidos. A typical Buddhist sees the world as a place of suffering and all he/she intends to do is to escape from this hellish world to a state that bears no resemblance whatever to this world. But in this giant stride towards perfection, the individual alone is capable of winning his/her salvation. All one needs to do is to practice the four cardinal truths which include the following:

1) That suffering is an accompaniment to the perpetual change of things,

2) That human desire is the cause of suffering,

3) That the suppression of desires is the only means to suppressing sorrows, and

4) The three stages once traversed, one arrives at the end of the road, at the deliverance, at salvation by nirvana (Durkheim, 1968: p. 45).

Another Asian religion which has similar conception of the world, of life and of salvation as Buddhism is Jainism. Jainism is one of the great Indian religions. The striking thing here is that Jainas behave like Buddhists. Durkheim makes Barth's view on this matter assessable as follows:

Like the Buddhists, the Jainas are atheists. They admit of no creators; the world is eternal; they explicitly deny the possibility of a perfect being from the beginning. The Jaina became perfect; he was not always so (p. 48).

According to Durkheim, Barth further explains that the attitudes and beliefs of Buddhists and Jainas are quite contrary to that of Christians. The point here is that Christianity is "inconceivable without the ever present idea of Christ and his ever-practiced cult; for it is by the ever-living Christ, sacrificed each day, that the community of believers continue to communicate with the supreme source of spiritual life” (pp. 47-48).

From our evaluation of religious notions of salvation it can be seen that every religion has its own conception of salvation. The same can be said of secularist notion of salvation to which we now turn.

\section{Theistic Humanism and Secularist Interpretations of Salvation}

Theistic humanism offers the opportunity for diverse interpretations of salvation from a secularist point of view. Secularism as a philosophical tenet can be regarded as those theories concerned with the analysis of our perpetual struggle towards freedom and perfection from a non-religious point of view. In secularist delineation of salvation, the question of freedom cannot be separated from the question of perfection. Perfection in this instance is a never ending quest towards the actualization of human freedom. In secularist terms, therefore, and especially from the Sartrean perspective, what religion classifies as the attainment of absolute freedom in the here-after, turns out to be prison life from which man must liberate himself, making the quest for salvation a never ending endeavour.

Hegel's philosophy and Kierkegaard's existentialism provide grounds from which both religious and secularist notions of salvation emerged. Hegel's theory of Absolute reason gave rise to the doctrine of "process or suffering God", which was further developed by Alfred North Whitehead. But the process or suffering God, though a companion, is unable to disentangle itself from human history. Applied to the doctrine of salvation, it would imply that the quest for salvation has no end in sight. 
Salvation thus becomes like a walking limbo. This is quite delicate for humans who mostly would prefer to seek for eternal salvation in the hereafter. Karl Marx rejects this religious interpretation and in its place substituted a purely secularist nation of salvation that is this-worldly. Marx's thesis has earlier been discussed in the introduction of this essay.

Reflecting on the influence of Kierkegaard's existentialism on both religion and secularism, Francis Schaeffer states thus: "From Kierkegaard, there are two extensions-secular existentialism and religious existentialism” (1968: p. 48). The main ethos of Kierkegaard's religious existentialism has already been discussed, leaving us with the delineation of his secular existentialism. Concerning Kierkegaard's secular existentialism, J. I. Unah states that "it is the bastardization of religion by over systematization and centralization that provoked Kierkegaard's orchestral blast upon Christendom” (1995: p. 55). In Unah's view therefore: "The paradox of faith is such that we cannot even say of others that they are Christians or Muslims let alone speak of a Christian nation or Muslim state. To speak thus is to rationalize religion. Yet a rationalized or organized religion is a fraud, a distraction and a delusion which robs the individual of his religious inwardness" (Ibid.).

For Kierkegaard, salvation is a personal or individual thing. But organized religion denies the individual of the franchise to freely relate with God, thereby infringing upon the capacity of the individual to attain salvation. Kierkegaard's criticism of absolutism (be it in philosophy or in religion) and his analysis of themes such as fear and dread, paved the way for the emergence of secular existentialism. In contemporary times, secular existentialism and Marxism have been described as atheistic philosophies. The reason for this is that most existentialists engage themselves strictly with the analysis of the human condition. Some like Heidegger make Being the ground of God, while others as Nietzsche and Sartre either declare the death of God or deny outrightly the existence of God. Marx on his part totally debunks the idea of spirit and by implication, the idea of God. Besides, his description of religion as opium of the people seems to suggest that religion is the deliberate manipulation of humans, which must be combated.

This secular atheistic opposition to religion is much expected, if not, mankind will forever remain under religious tutelage without hope of liberation in sight. In this wise, atheism is not just an opposing view to theism, it is rather a clarion call for humankind to imbibe the attitude of self-reliance. In which case, the goal of atheism, it would seem, is to liberate fettered humans from the grip of religion. In which case, the intention of the atheist is to assert his/her freewill without fear or favour of the intimidating views of theism which hangs the guilt of God and the world on the frail neck of man. Thus, like T. D. P. Bah asserts:

The atheist is a religious man and moreover, he is a fanatic believer. He believes that he has found the truth which other men cannot discover. His truth, however, is different from that of Jesus or Mohammed. The atheist is one who has come with another message about man, about science, about technology ... Unfortunately the atheist's criterion of truth is not any better than the religious leader (1997: p. 159).

Salvation for the existentialists involves living an authentic life as opposed to a life of forfeiture. To lead an authentic life is to be free and to be free means to be responsible. Humankind has to strive to square up with life's challenges; to do otherwise is simply an act of bad fate. In the views of Sartre and Heidegger, because human existence is characterized by nothingness, the march towards freedom is unending. Jean-Paul Sartre says that "man is a being who is not what he is and who is what he is not” (1969: p. 23). For Martin Heidegger, man is a being-who is more than what he is at any given time. Since nothingness constitutes the foundation of human existence, it means that human life is futuristic and open ended, making us beings of transcendence. This ontological endowment makes us beings of possibilities with insatiable desires. This way, the quest for salvation becomes a continuum.

From the philosophies of Heidegger and Nietzsche developed what can be described as "New Theologies". Following Heidegger's theory of Sein (i.e. Being), Paul Tillich developed a new concept of God in which he describes God as the being of beings or the ground of beings. Tillich as such, speaks of the "God behind God-with the first God totally undefined" (Schaeffer, 52). By this Tillich’s doctrine, says Schaeffer, salvation faces a comatose. The search for salvation becomes like a hopeless quest or a hovering in the dark. In the same vein, Nietzsche's declaration of the death of God became a hangover for some Christian theologians such as Thomas Altizer and William Hamilton who developed "The Death of God Theology” also variously known as Radical Theology, Atheistic Theology, or Christian Atheism. The central message of this movement is that God ceased to be transcendent from the moment he incarnated in the person of Jesus Christ of Nazareth who finally died on the cross. From that moment humans won their total freedom. According to Christian Atheism, the death of God is "good news" to humans. Consequently, what Christians should do is to announce to the world the historic death of God, which signals our freedom, our salvation. In the words of Altizer: "True, every man today who is open to experience knows that God is dead, that the Christian knows that God is dead, that the death of God is a final and irrevocable event, and that God's death has actualized in our history a new and liberated humanity" (1955: p. 15).

Another angle to secularist notion of salvation is liberation theology which combines the tenets of Marxism, Existentialism and Christianity. Liberation theology locates God and humans in the daily existential, historical and economic activities of the society. According to Bonino, liberation theology "was born in the context of the struggle for the liberation of man, it very much emphasizes a concrete man in a concrete historical situation for only such a man needs liberation, not an abstract nor an invisible man” (cited by Uzukwu, 1988: p. 175). In this context, liberation refers to the struggle by humans to emancipate themselves from the shackles of oppression. The apostles of Liberation theology include such names as Ruben Alves and Jose Miguez Bonino, with Paulo Freire providing the educational foundation for the movement or what can be called pedagogy for the liberation of the oppressed.

The beauty of liberation theology is that it is concerned with the liberation of all humans. For total liberation to be achieved, both the oppressed and the oppressor must be emancipated. In the first place, there can be no oppressed without the oppressor and vice versa, and both suffer from the psychology of fear and domination. Complete freedom, and by implication complete salvation can only be achieved when the oppressed and oppressor have been emancipated. Paulo Freire describes this constant strive towards freedom (i.e. salvation) as "mans onto- 
logical vocation” (p. 177). Alves on his part, sees human existence as a "creation of history and this is made possible through man's historical exercise of power to overcome the contradiction (negation) of man's inhumanity-towards freedom and transcendence" (p. 178). It is by constantly striving to negate human inhumanity that harmony can be achieved on earth and by so doing actualize the dream of a kingdom of God for humans. This point is aptly captured by Bonino thus:

God builds his kingdom from and within human history in its entirety; his action is a constant call and challenge to man. Man's response is realized in the concrete arena of history with its economic, political, ideological options. Faith is not a different history but a dynamic motivation, and in its eschatological horizon, a transforming invitation (Ibid).

Thus far it can be seen that secularism like religion presents different conceptions of salvation. These various conceptions of salvation show that reality is multidimensional, multifaceted and diverse and so is salvation. Since salvation cannot be pigeonholed, it is then left for everyone to choose a perspective out of the so many existing theories of salvation.

\section{Evaluation and Conclusion}

The whole talk about salvation centers on the question of human freedom. Are humans truly free to make their own choices from the notions of salvation catalogued above or not? The answer(s) to the foregoing question will go a long way to further enhance our understanding of the issue at hand. If really humans are determined, then there may be some reason to fight for liberation. And if humans are totally free, would there still be any need to strive for salvation or for emancipation? Sartre offers us a clue to this puzzle. The fact that man is not in any way determined does not mean that he is free from challenges and responsibilities. Whichever way we look at it, without some hurdles to scale and some goals to achieve, human life would be completely worthless. This particular fact, makes the debate on salvation worthwhile. The greater trouble however, concerns the point that monistic notions of salvation, whether religious or secular, have the tendency to limit our freedom to decide on our perspectives of salvation. This is why this essay privileges non-monistic/non-monotheistic notions of salvation over and above the monistic/monotheistic notions of salvation. This position is meant to avoid absolutism and intolerance and to inculcate the attitude of live and let live or the win win orientation, which happens to be the hallmark of theistic humanism, towards the salvation talk.

As earlier mentioned, theistic humanism with its doctrine of polymonotheism, which is further embellished by the concepts of pantheism and panpsychism, demonstrates the fact that the debate over salvation is better approached from the pluralistic outlook. This inspiration gathered from Maduabuchi Dukor is further reiterated by J. I. Unah and Chinweizu. In Essays in Philosophy and "Gender and Monotheism: The Assault by Monotheism on African Gender Diarchy” J. I. Unah and Chinweizu respectively, attempt an analysis of the sources of absolutism in philosophy and religion. Unah for instance, holds the view that-the seeds of intolerance and fanaticism were sown by the Greek search for certainty which has fossilized into vengeful metaphysical systems. This sort of metaphysical thinking manifests itself in two main forms. Either that it re- duces all reality to some common substance or that it focuses attention on an ultimate divine Being. The result is that it narrows down the telescope with which the whole of reality is viewed. The narrower a metaphysician's position becomes, the sharper his/her perspective, but the shaper his/her perspective, the greater the scandal such perspective perpetrates against other aspects of reality not accommodated by his/her system. This lack of courage to accept opposing views says Unah is injurious to human progress because "By insisting that his perspective encompasses the totality of being, the metaphysician creates an orthodoxy - a total system of norms and valuesfrom which every other mortal must not deviate, thereby extolling an attitude of fixism, fanaticism and intolerance" (1995: p. 67). Chinweizu on his part traces the source of absolutism to Akhenatonism or Atenism, which happened to be the oldest form of monotheism founded by Akhenaton of ancient Egypt, which at that period lasted for only thirty years. But in its brief existence, Atenism had introduced the orientations of monism and monotheism and their propensities to abhor duality and pluralism. According to Chinweizu, "though it (Atenism) vanished, its brief life brought into the world the great evils of monotheism and its propensities for monomania, monolatry and zealotry" (2005: p. 139).

From Atenist monotheism evolved patriarchal monotheism namely Judaism or Yahwehism, Christianity and Islam, which are regarded as West Eurasian heirs to Atenism, and along with Atenism propagate "the monistic attribute to deity, the massculinization of the sole deity and the rise of cultural monolatry" (pp. 140-141). In logical and natural order, patriarchal monotheism gave rise to monistic and absolutist trends of thought (such as Liberalism, Marxism and Feminism) in Western scholarship. The trauma liberalism (capitalism per se) and Marxism caused the world in the 20th century cannot be easily forgotten. The world lived in constant fear of the outbreak of nuclear war. Needless to say, such fear of outbreak of nuclear war has been rekindled in the 21st century by the rift between Israel, Europe and the United States on one side, and Russia, China, North Korea and Iran on the other side. Besides: "In the Feminism of the late 20th century, liberalism and Marxism have jointly spawned a movement for the propagation of their gender ideologies. Through its liberal and Marxist wings, feminism seeks to carry out the agendas of liberalism and Marxism. Thus, like liberalism and Marxism, feminism attacks gender dualism” (p. 142).

Since both religion and secularism espouse temperaments that promote dogmatism, absolutism and intolerance, it means that there is a need to make evaluations of both perspectives with a view to ameliorating the anomalies inherent in them. This might be the reason why Ludwig Feuerbach merciless lashed at religious anthropomorphism. He accused anthropomorphic religions of alienating humans from their essential attributes and of investing such qualities on an intangible GodHead, who contributes nothing of substance to human development. Feuerbach goes ahead to argue that God is but man's self-projection. "Consciousness of God is self-consciousness, knowledge of God is self-knowledge. By his God thou knowest the man, and by the man his God; the two are identical. Whatever is God to a man, that is his heart and soul, God is the manifested inward nature, the expressed self of a man” (1989: p. 13).

By enriching God, humans impoverish themselves. Worst of all, the God they end up creating is a self-centered being who 
cares little about their plight.

To enrich God, man must become poor; that God may be all; man must be nothing ... God, the Almighty, infinite unlimited being, is a person, he denies human dignity, the human ego; he is a selfish, egoistical being, who seeks himself alone, his own honour, his own ends ... God is the very luxury of human egoism (pp. 26-27).

Feuerbach sees religion as the source of human disunity and unhappiness. The way out of this human disharmony, sorrow and alienation, is for humans to reclaim what they have invested upon God so that they can re-attain the God's status. In the light of this, Feuerbach embarked on the secularization religion, with the intention of crafting a platform that would make humans ascend the pedestal of goodness. To ascend the pedestal of goodness is to make love the central theme of our existence. "Love happens to be the supreme law of human life; it is the most profound essence of man. Love assumed fantastic forms in all religions. But in reality, it is itself a true religion. Love is God himself, and outside love there is no God (Kuznetsov, 1987: p. 55). Needless to say, this Feuerbachian position was hinted at by Immanuel Kant whose critical ontology made human reason the ultimate organizer of all human affairs, including law, morality, religion and society in general. By implication, the question of salvation is entirely a human affair, it is a self imposed duty, and the realization this should spur us into adopting a pluralistic a approach toward resolving the debate on salvation

Fortunately, theistic humanism, which forms the essence African thought system, affords us the opportunity of a pluralistic outlook. This can be seen in the Igbo (of South-East Nigeria) proverb egbe bere ugo bere; nke si ibeya ebela nku kwaya, meaning-let the hawk perch, let the eagle perch, whichever says the other should not perch, let its wings be broken. And the Yoruba South-West of Nigeria say oju orun to gbogbo eye lato fo lai kan ara won, meaning - the sky is big enough for all birds to fly without touching each other. The point here is that African thought system, like the phenomenological temperament, acknowledges the fact that conflict and contraries are parts and parcels of the universe, and of course, human existence. But if we adopt the "win win" attitude or the "live and let live" orientation, there would be greater harmony in the world, making it a better place to live in. This happens to be the highpoint of the hermeneutic appraisal of salvation from the perspective of theistic humanism.

\section{REFERENCES}

Alao, N. (1988). Designing peace, tolerance and understanding. Being the introduction to Nigerian studies in religious tolerance; Volume I: Religions and Their Doctrines (C. S. Momoh, M. S. Zahradeen, \& S. O. Abogunrin, Eds.). Lagos: Centre for Black African Arts and Civilization (CBAAC) and National Association for Religious Tolerance (NARETO).

Altizer, T. (1955). The gospel of Christian Atheism. London: Collins.

Bah, T. D. P. (1997). Religion, god, and foreign culture in Africa. In Philosophy and metaphysics: A critical introduction. Lagos: Obaroh and Ogbinaka Publishers Limited.

Chinweizu (2005). Gender and monotheism: The assault by monotheism on African gender diarchy. In Anatomy of female power (New Edition). Lagos: Pero Press.

Dukor, M. (2010). Theistic humanism of African philosophy: The great debate on substance and method of African philosophy. Berlin: LAP LAMBERT Academic Publishing GmbH \& Co. KG.

Durkheim, E. (1968). The elementary forms of the religious life. New York: The Free Press.

Eboh, B. O. (1993). God in Igbo ontology. Being a Paper Delivered at an International Conference Organized by Nigerian Philosophical Association, at University of Lagos Conference Centre.

Feuerbach, L. (1989). The essence of Christianity. New York: Prometheus Books.

Good News Bible (1991). Lagos: The Bible Society of Nigeria.

Heidegger, M. (1962). Being and time. Oxford: Basil Blackwell.

Kuznetsov, V. N. (1987). Engels, Ludwig Feuerbach and the end of classical German philosophy. Moscow: Progress Publishers.

Marx, K. (1969). Economic and philosophic manuscript of 1844. Moscow: Progress Publishers.

Microsoft Encarta Premium (2009). Microsoft Corporation.

Nauman, St. E. (1979). Dictionary of Asian Philosophies. London: Routledge \& Kegan Paul.

Nietzsche, F. (1971). Thus Spake Zarathustra. London: Penguin Books.

Noss, J. B. (1990). Mankind's search for god. New York: Watchtower Bible and Track Society.

Ogundowole, E. K. (1988). Self-reliancism: Philosophy of a new order. Lagos: John West Publication Ltd.

Ogundowole, E. K. (2002). The origin and definition of man. In E. K. Ogundowole (Ed.), Man, history and philosophy of science: A compendium of readings. Lagos: Department of Philosophy.

Rampa, T. L. (1956). The third eye. London: Gorgi Books.

Sartre, J. P. (1969). Being and nothingness. London: Methuen Co. Ltd.

Schaeffer, F. A. (1968). Escape from reason. England: Inter-Varsity Press.

Unah, J. I. (1995). Essays in philosophy. Lagos: Panaf Incorporation.

Uzukwu, E. E. (1988). Religion and African culture. Enugu: SNAAP Press Ltd.

Williams, B. (1999). Stage lighting design. Parts 1-4 Editions, 2c \& 2d. On Internet. 